Ostatni cykl wystapień dotyczył relacji człowiek - społeczeństwo w jej różnych aspektach. Obradom przewodniczył prof. Stanisław Suchodolski (Warszawa). Rozpoczał dr Przemysław Wiszewski (Wrocław) referatem dotyczacym poczatków tradycji rodowej Piastów, później dr Wojciech Mrozowicz (Wrocław) zajał się architektura kościoła zamkowego w Oleśnicy. Dalsze wystapienia dotyczyly wielkich rodów szlacheckich i mechanizmów ich społecznego awansu: dr Filip Wolański (Wrocław), dr Dariusz Rolnik (Katowice) oraz mgr Igor Wypijewski (Wroclaw). Mentalnością i stosunkami społecznymi wśród ludności normańskiej w XI w. zajął się mgr Przemysław Kulesza (Wrocław). Prof. Antoni Barciak (Katowice) przedstawił skład spoleczny średniowiecznego bractwa Najświętszej Marii Panny w Raciborzu, dr Iwona Pieprzyk (Katowice) i mgr Marcin Marcin Pauk (Warszawa) przybliżyli zagadnienia związane z czeskim spoleczeństwem doby Przemyślidów, a mgr Michał Gronowski OSB (Tyniec) dokonał prezentacji społeczności klasztoru tynieckiego w XVI-XVIII w. w świetle księgi profesyjnej. Relacje między szlachta a chłopami znalazły odzwierciedlenie w tekstach wystąpień dr Piotra Badyna i mgr Pawla Klinta (Wrocław), kończących drugi dzień obrad.

Ostatni dzień konferencji rozpoczął się od dyskusji nad referatami oraz podsumowaníem dokonań naukowych sympozjum, którego dokonal prof. Jerzy Strzelczyk (Poznań). Zorganizowano ponadto wyjazdy turystyczne na zamek w Zagórzu i zwiedzanie podziemi w Osówku. Podkreślić należy znakomita organizacje i atmosferę towarzysząca obradom i merytorycznym dyskusjom, w których uczestniczyło kilkudziesięciu uczonych z czołowych ośrodków akademickich kraju - specjalistów z dziedziny historii, historii sztuki, archeologii, źródloznawców, etnologów, geografów, socjologów i kulturoznawców.

Krzysztof Ratajczak

\title{
V Ogólnopolski Zjazd Peadgogiczny Polskiego Towarzystwa Pedagogicznego (Wrocław, 23 - 25 września 2004)
}

We wskazanych powyżej dniach odbył się kolejny, V Zjazd PTP, którego organizację Towarzystwo powierzyło Dolnośląskiej Szkole Wyższej Edukacji TWP we Wrocławiu. W Zjeździe wzięło udział ponad 560 uczestników (zarówno teoretyków i badaczy edukacji, jak i wielu praktyków wychowania). Jak zawsze - choć w skromniejszej liczbie - w Zjeździe uczestniczyli również historycy wychowania. Swój udział zaznaczyli oni przede wszystkim w piątej tematycznej Sekcji Zjazdu - „Teraźniejszość w dialogu z edukacyjna przeszłościa". Obradami w sekcji kierowali prof. Jerzy Semków i prof. Sławomir Sztobryn.

O znaczeniu refleksji historycznej w pedagogice mówił w Sekcji m.in. S. Sztobryn. Swoim wystapieniem dokonał on swoistego wprowadzenia do dyskusji na temat aktualnego stanu, dorobku i statusu metodologicznego historii wychowania. Duże ożywienie w dyskusji wywołały jednak przede wszystkim treści referatu Gościa Sekcji - prof. Teresy Hejnickiej-Bezwińskiej.

Wiesław Jamrozek 